\title{
Isolation of RNA from milk somatic cells as an alternative to biopsies of mammary tissue for nutrigenomic studies in dairy ewes
}

\author{
P. G. Toral, ${ }^{*}$ G. Hervás, ${ }^{* 1}$ A. Suárez-Vega, † J. J. Arranz,† and P. Frutos* \\ *Instituto de Ganadería de Montaña (CSIC-ULE), Finca Marzanas s/n, 24346 Grulleros, León, Spain \\ †Departamento de Producción Animal, Facultad de Veterinaria, Universidad de León, 24071, León, Spain
}

\begin{abstract}
Nutrigenomic studies of mammary lipogenesis in ruminants often rely on the use of mammary tissue (MT) collected either by biopsy or at slaughter. However, isolating RNA from milk would be a useful and cost-effective technique that may avoid distress to the animal and facilitate the collection of samples in time series experiments. This assay was therefore conducted to test the hypothesis that RNA extracted from milk somatic cells (MSC) in dairy sheep would be a feasible alternative to the performance of MT biopsies for nutrigenomic analyses. To meet this objective, 8 lactating Assaf ewes were divided in 2 groups and offered a total mixed ration without supplementation (control) or supplemented with $2.4 \%$ dry matter of fish oil, which was known not only to elicit milk fat depression but also to downregulate the expression of some candidate genes involved in mammary lipogenesis. Total RNA was extracted from MSC and biopsied MT to examine whether the potential changes in the abundance of transcripts was similarly detected with both RNA sources. Milk fatty acid profile was also analyzed by gas chromatography, and variations in mRNA abundance were determined by reverse transcription quantitative PCR. Values of RNA integrity number were always 27.7. The expected and designed decrease of milk fat concentration with fish oil $(-29 \%)$, was associated with a lower transcript abundance of genes coding for enzymes involved in fatty acid activation (ACSS1), de novo synthesis ( $A C A C A$ and $F A S N)$, uptake from plasma lipids $(L P L)$, and esterification of fatty acids to glycerol (LPIN1), as well as of a transcription factor that may regulate their expression (INSIG1). Stable mRNA levels were showed in other candidate genes, such as FABP3, GPAT4, or SCD. Changes due to the dietary treatment were similarly detected with both
\end{abstract}

Received March 17, 2016.

Accepted June 26, 2016.

${ }^{1}$ Corresponding author: g.hervas@csic.es
RNA sources (MSC and MT biopsies), which supports the initial hypothesis and would validate the use of milk as an alternative RNA source for nutrigenomic analyses in dairy sheep.

Key words: fatty acid, fish oil, gene expression, RNA source, sheep

\section{INTRODUCTION}

Nutrigenomics is a novel and promising discipline that studies the effect of nutrition on physiological processes by altering gene expression (Bauman et al., 2011). Although the greater availability of DNA sequences in livestock has allowed for significant advances in this field (Shingfield et al., 2010; Bionaz et al., 2015), most aspects on molecular mechanisms involved in the nutritional regulation of mammary lipogenesis in ruminants are still uncertain.

In vivo studies have shown that milk fat depression (MFD) due to trans-10,cis-12 CLA administration is associated with downregulation of mammary genes encoding key lipogenic enzymes (e.g., $A C A C A, F A S N$, $L P L$, and $S C D$; Harvatine and Bauman, 2006; Gervais et al., 2009; Hussein et al., 2013). On the contrary, scarce and inconsistent data are available on the effects of plant oils or marine lipids on the mRNA abundance in the mammary gland of cows (Peterson et al., 2003; Invernizzi et al., 2010; Angulo et al., 2012) and ewes (Bichi et al., 2013a; Castro-Carrera et al., 2015; Carreño et al., 2016). Therefore, further in vivo research would be strictly necessary to advance the state-of-the-art in the interaction between nutrients, gene expression, and milk fat synthesis.

Nutrigenomic studies often rely on the use of mammary tissue (MT) collected either by biopsy or at slaughter (e.g., Harvatine and Bauman, 2006; Invernizzi et al., 2010; Bichi et al., 2013a). Nonetheless, the validation of a technique of RNA extraction from milk would bring clear advantages in terms of animal welfare, economic cost, and feasibility to conduct repeated samplings over time. However, wide discrepancies exist among the very few reports on the comparative use of 
RNA isolated from either MT or milk for studying the nutritional regulation of mammary lipogenesis in cows (Murrieta et al., 2006; Angulo et al., 2012), which are probably related to the methodological approaches. In this regard, Cánovas et al. (2014) showed the suitability of an RNA extraction procedure from milk somatic cells (MSC) to characterize the lactating bovine mammary gland transcriptome. This protocol has recently been adapted to ovine and used to examine the pattern of gene expression throughout the lactation in 2 dairy sheep breeds (Suárez-Vega et al., 2015).

The present assay was conducted to test the hypothesis that isolation of RNA from MSC in dairy ewes would be a feasible alternative to the performance of MT biopsies for nutrigenomic analyses. To meet this objective, we fed a group of sheep a diet supplemented with fish oil, which has been shown not only to elicit MFD but also to decrease the mRNA abundance of some candidate genes involved in mammary lipogenesis (Carreño et al., 2016). Then, we extracted RNA from MSC and from biopsied MT to examine whether the potential changes in the expression of those genes may be similarly detected with both RNA sources. Milk fatty acid profile was also analyzed and related to transcript abundances.

\section{MATERIALS AND METHODS}

\section{Animals, Experimental Design, and Management}

All experimental procedures were approved and completed in accordance with the Spanish Royal Decree $53 / 2013$ for the protection of animals used for experimental purposes (BOE, 2013). Eight lactating Assaf ewes $(\mathrm{BW}=82.5 \pm 2.45 \mathrm{~kg}$; DIM $=62 \pm 2.5$; parity $=2 \pm 0.3 ;$ milk yield $=1.8 \pm 0.14 \mathrm{~kg} / \mathrm{d}$ ) were housed in individual tiestalls and divided into 2 groups $(\mathrm{n}=$ 4), balanced according to milk yield and composition, BW, DIM, and parity. Groups were assigned to 1 of 2 dietary treatments, consisting of a TMR based on alfalfa hay and concentrates (forage-to-concentrate ratio 40:60) without lipid supplementation (control) or supplemented with $24 \mathrm{~g}$ of fish oil (Afampes 121 DHA; Afamsa, Mos, Spain) $/ \mathrm{kg}$ of diet DM (FO). The ingredients of the experimental diets, which were prepared weekly, are presented in Table 1 . All ewes were fed the control diet for a 21-d adaptation period, and then both experimental treatments for 40 more days. Fresh diets were offered daily ad libitum at approx. 0900 and $1900 \mathrm{~h}$ and refusals were removed and weighed each morning. Clean water was always available. Ewes were milked twice daily at 0830 and $1830 \mathrm{~h}$ in a single-side milking parlor with 10 stalls (DeLaval, Madrid, Spain).

\section{Measurements and Sampling Procedures}

Milk. At the end of the adaptation period ( $\mathrm{d}-2$ and 0 ), and after 35 and $37 \mathrm{~d}$ on treatments, milk yield was recorded and individual milk samples were collected and composited according to morning and evening milk yield. One aliquot of composite milk was preserved with bronopol (D\&F Control Systems Inc., San Ramon, CA) and stored at $4^{\circ} \mathrm{C}$ until analyzed for fat concentration. Milk fatty acid (FA) composition was determined in untreated samples that were stored at $-30^{\circ} \mathrm{C}$ until analysis.

On d 38 and 39, milk samples were collected for RNA extraction. Following the protocol by Suárez-Vega et al. (2015), udders were cleaned with water and soap and then disinfected with povidone iodine. Nipples were also washed with RNaseZap (Ambion, Austin, TX). To maximize the number of somatic cells in milk, samples were collected approximately $1 \mathrm{~h}$ after morning milking (Gonzalo et al., 1994) and 10 min after the injection of oxytocin (5 IU/animal; Facilpart, Laboratorios SYVA,

Table 1. Formulation and chemical composition of the TMR without lipid supplementation (control) or supplemented with $24 \mathrm{~g}$ of fish oil/ $\mathrm{kg}$ of DM (FO)

\begin{tabular}{|c|c|c|}
\hline \multirow[b]{2}{*}{ Item } & \multicolumn{2}{|c|}{ TMR } \\
\hline & Control & $\mathrm{FO}$ \\
\hline \multicolumn{3}{|l|}{ Ingredients, $\mathrm{g} / \mathrm{kg}$ of fresh matter } \\
\hline Dehydrated alfalfa hay, particle size $>4 \mathrm{~cm}$ & 400 & 391 \\
\hline Whole corn grain & 180 & 176 \\
\hline Whole barley grain & 130 & 127 \\
\hline Soybean meal solvent, $440 \mathrm{~g}$ of $\mathrm{CP} / \mathrm{kg}$ & 150 & 147 \\
\hline Sugar beet pulp, pellets & 70 & 68 \\
\hline Molasses, liquid & 50 & 49 \\
\hline Fish oil $^{1}$ & 0 & 22 \\
\hline Vitamin-mineral supplement & 20 & 20 \\
\hline \multicolumn{3}{|l|}{ Chemical composition, $\mathrm{g} / \mathrm{kg}$ of DM } \\
\hline $\mathrm{OM}$ & 902 & 901 \\
\hline $\mathrm{CP}$ & 176 & 171 \\
\hline NDF & 305 & 306 \\
\hline $\mathrm{ADF}$ & 208 & 209 \\
\hline Starch & 171 & 167 \\
\hline Total fatty acids & 18.2 & 40.3 \\
\hline 14:0 & 0.24 & 1.14 \\
\hline $16: 0$ & 3.91 & 8.20 \\
\hline cis-9 16:1 & 0.04 & 1.06 \\
\hline 18:0 & 0.80 & 1.93 \\
\hline cis-9 18:1 & 2.89 & 6.66 \\
\hline cis-11 18:1 & 0.22 & 0.95 \\
\hline $18: 2 \mathrm{n}-6$ & 6.78 & 7.26 \\
\hline $18: 3 n-3$ & 2.22 & 2.39 \\
\hline $20: 5 n-3$ & 0.00 & 1.49 \\
\hline $22: 5 n-3$ & 0.00 & 0.34 \\
\hline $22: 6 \mathrm{n}-3$ & 0.00 & 4.55 \\
\hline
\end{tabular}

${ }^{1}$ Semirefined tuna and sardine oil (Afampes 121 DHA; Afamsa, Mos, Spain); contained (g/100 g of total fatty acids): 14:0 (4.0), 16:0 (19.2), cis-9 16:1 (4.5), 17:0 (1.5), 18:0 (5.0), cis-9 18:1 (16.8), cis-11 18:1 (3.2), 18:2n-6 (2.8), 18:3n-3 (1.0), cis-11 20:1 (1.8), 20:5n-3 (6.5), $22: 5 n-3$ (1.5), and 22:6n-3 (19.9). 
León, Spain). Individual samples were obtained by hand-milking both halves of the mammary gland into an RNase-free 50-mL tube, which was covered with a sterile gauze to filter the milk. Samples were held in ice and transferred immediately to the laboratory for RNA extraction.

Biopsies. On d 40, mammary tissue samples were biopsied from each ewe. After local anesthesia of the area by subcutaneous injection of lidocaine (Anesvet, Laboratorios Ovejero S.A., León, Spain), a 4-cm incision was made at the midpoint section of a half-udder, through the skin and underlying fascia until the mammary capsule was clearly visible. Tissue samples $(\approx 20$ $\mathrm{mg}$ ) were collected using disposable needles (12 gauge $\times$ 10 cm; MN1210, Bard Magnum, Bard Biopsy Systems, Tempe, AZ) for a Magnum reusable core biopsy instrument (MG1522, Bard Biopsy Systems), immediately frozen in liquid $\mathrm{N}_{2}$, and stored at $-80^{\circ} \mathrm{C}$ until RNA extraction. Briefly [see Toral et al. (2015b) for details], the wound was treated with adrenaline, and the incision was closed with suture clips and sprayed with topical antibiotic and a wound-healing product. Ewes also received injections of antibiotic, anti-inflammatory, and systemic hemostatic drugs. No incidences of mastitis were detected for any ewe in the study.

\section{Laboratory Analysis}

Diets and Orts. Dry matter concentration in diets and orts was determined according to the ISO (1999a) standard. Diets were also analyzed for ash (ISO, 2002) and CP (ISO, 2009). The NDF and ADF were determined using an Ankom ${ }^{2000}$ fiber analyzer (Ankom, 2006a,b); the former was assayed with sodium sulfite and $\alpha$-amylase, and both were expressed with residual ash. Fatty acid methyl esters of lipid in diets were prepared in a 1-step extraction-transesterification procedure using chloroform (Sukhija and Palmquist, 1988), $2 \%$ (vol/vol) sulfuric acid in methanol (Shingfield et al., 2003), and cis-12 tridecenoate (Larodan, Solna, Sweden) as an internal standard. Methyl esters were separated and quantified using a gas chromatograph (Agilent 7890A GC System, Santa Clara, CA) equipped with a flame-ionization detector and a 100-m fused silica capillary column $(0.25 \mathrm{~mm}$ i.d., $0.2-\mu \mathrm{m}$ film thickness; CP-SIL 88, CP7489, Varian Ibérica S.A., Madrid, Spain) and hydrogen as the carrier gas (207 kPa, $2.1 \mathrm{~mL} / \mathrm{min}$ ). Total FAME profile in a $2-\mu \mathrm{L}$ sample volume at a split ratio of 1:50 was determined using the temperature gradient program described in Shingfield et al. (2003). Peaks were identified based on retention time comparisons with commercially available standard FAME mixtures (from Nu-Chek Prep., Elysian, MN, and Sigma-Aldrich, Madrid, Spain).
Milk. Fat concentration was determined by infrared spectrophotometry (ISO, 1999b) using a MilkoScan FT6000 (Foss, Hillerød, Denmark), combined with a fluoro-opto-electronic counter (Fossomatic FC, Foss) for milk SCC (ISO, 2006). Lipid in $1 \mathrm{~mL}$ of milk was extracted using diethylether and hexane (5:4, vol/vol) and converted to FAME by base catalyzed transesterification (Shingfield et al., 2003). The total FAME profile was determined by GC using the same chromatograph and temperature gradient program applied for the analysis of feeds, but isomers of 18:1 were further resolved in a separate analysis under isothermal conditions at $170^{\circ} \mathrm{C}$ (Shingfield et al., 2003). Peaks were identified based on retention time comparisons with the same FAME mixtures used for the analysis of feeds, other commercially available standards (from Nu-Chek Prep., Sigma-Aldrich, and Larodan), and comparison with reference samples for which the FA composition was determined based on GC analysis of FAME and GC-MS analysis of corresponding 4,4-dimethyloxazoline derivatives (Bichi et al., 2013b).

RNA Isolation and Quantitative PCR. Total RNA in $50 \mathrm{~mL}$ of fresh milk was extracted as described by Wickramasinghe et al. (2012), with modifications reported by Suárez-Vega et al. (2015). Briefly, MSC were pelleted by centrifugation at $650 \times g$ for $10 \mathrm{~min}$ at $4^{\circ} \mathrm{C}$ in the presence of a final concentration of $0.5 \mathrm{mM}$ EDTA. The cell pellet was washed with $10 \mathrm{~mL}$ of PBS (pH 7.2 and $0.5 \mathrm{~m} M$ EDTA) followed by another centrifugation at $650 \times g$ for $10 \mathrm{~min}$ at $4^{\circ} \mathrm{C}$. The washing and centrifugation procedure was repeated twice more using 2 and $1.5 \mathrm{~mL}$ of the same PBS solution. Then, total RNA was extracted and purified from the milk cell pellet with TRIzol (Invitrogen, Carlsbad, CA), as outlined previously (Suárez-Vega et al., 2015).

Total RNA from the MT biopsies was isolated and purified using a commercially available kit (PureLink RNA Mini Kit, Invitrogen) as described in Bonnet et al. (2013), with the exception that the tissue was homogenized with a bead beater disruptor (Mini-bead Beater-8, BioSpec Products, Bartlesville, OK).

The RNA concentration was determined by fluorometry (Qubit 3.0; Life Technologies, Carlsbad, CA), and RNA integrity number (RIN) by capillary electrophoresis (Agilent 2100 Bioanalyzer, Agilent Technologies Inc.). For quantitative PCR (qPCR) analysis, cDNA was synthesized from $1.5 \mu \mathrm{g}$ of RNA from each sample through the High Capacity RNA-to-cDNA Kit (Applied Biosystems, Foster City, CA). The lack of DNA contamination was verified by a PCR amplification with $A C T B$ primers flanking an intron. Specific primers were synthesized (Eurofins Genomics, Ebersberg, Germany) for the following genes: acyl-CoA synthetase short-chain family member 1 (ACSS1), involved 
in FA activation; acetyl-CoA carboxylase $\alpha(A C A C A)$ and fatty acid synthase $(F A S N)$, involved in de novo FA synthesis; lipoprotein lipase $(L P L)$ and fatty acidbinding protein 3 (FABP3), involved in the uptake and intracellular transport of $\mathrm{FA}$; stearoyl-CoA desaturase (delta-9-desaturase; $S C D$ ), involved in $\Delta^{9}$-desaturation of FA; glycerol-3-phosphate acyltransferase 4 (GPAT4) and lipin 1 (LPIN1), involved in the esterification of FA to glycerol; and transcription factors sterol regulatory element binding transcription factor 1 (SREBF1) and insulin-induced gene 1 (INSIG1). The qPCR was carried out (Bonnet et al., 2013) using a 7500 RealTime PCR System (Applied Biosystems). To account for variations in RNA integrity and quantification and cDNA synthesis, mRNA abundance was normalized using the geometric mean of 3 reference genes: eukaryotic translation initiation factor 3 subunit K (EIF3K), peptidylprolyl isomerase A (PPIA), and ubiquitiously expressed prefoldinlike chaperone $(U X T)$, which have been identified as suitable internal controls (Bionaz and Loor, 2007; Bonnet et al., 2013). Gene stability was examined using the geNorm (Vandesompele et al., 2002) and BestKeeper procedures (Pfaffl et al., 2004). The primer sequences and qPCR performance are shown in Table 2. The abundance of gene transcripts was calculated using a 5-point calibration curve generated from the serial dilution of a cDNA pool, prepared by mixing equal volumes of all MT and MSC samples, and was expressed as the $\log _{2}$ value of mRNA copy number relative to the geometric mean of the 3 reference genes.

\section{Calculations and Statistical Analysis}

All statistical analyses were performed using the MIXED procedure of the SAS software package (version 9.4, SAS Institute Inc., Cary, NC). Animal performance and FA composition data were analyzed by one-way ANCOVA with a model that included the fixed effect of experimental diet (mean values over d 35 and 37) and measurements at the end of the adaptation period (mean values over $\mathrm{d}-2$ and 0 ) as a covariate. Thus, covariate-adjusted least squares means are reported. Transcript mRNA abundance data were analyzed by ANOVA to test the fixed effects of experimental diet (D), the RNA source $(\mathbf{S})$ and their interaction $(\mathrm{D} \times$ $\mathrm{S})$. In all cases, animals were nested within the treatment and used as the error term to contrast the effect of treatments. Means were separated using the pdiff option of the lsmeans statement of the MIXED procedure. The CORR procedure was used to generate the Pearson correlation coefficient $(r)$ for the association between qPCR results (quantification cycles, $\mathrm{Cq}$ ) for the whole set of genes studied in MT and MSC.

\section{RESULTS}

\section{Animal Performance and Milk Composition}

Compared with the control (Table 3), feeding fish oil decreased milk fat concentration $(5.87$ vs. $4.19 \% ; P<$ 0.01). However, no significant differences were detected in milk fat yield $(P>0.10)$ due to the $31 \%$ increase in milk production in ewes fed this lipid supplement. The experimental diet had no effect on DMI or milk SCC $(P>0.10)$.

\section{Milk FA Composition}

As expected, milk FA composition (Table 4) was significantly affected by the addition of fish oil to the diet, although it hardly modified the concentration of milk FA synthesized de novo in the mammary gland (including cis-9 10:1, cis-9 12:1, and cis-9 14:1), except for a reduction in 15:0 $(P<0.05)$. However, changes in some 16- and in 18-carbon intermediate metabolites were notable and included an increase in the milk percentage of 2 CLA isomers with potential (trans-9, cis-11 18:2) or confirmed (trans-10,cis-12 18:2) antilipogenic effects $(P<0.05)$. Although numerical differences in the candidate milk fat inhibitor trans-10 18:1 did not attain statistical significance $(P>0.10)$, FO supplementation increased the concentration of most other trans FA (e.g., trans-11 18:1, cis-9,trans-11 CLA, or trans-11,cis-15 and trans-11,trans-15 18:2; $P<0.05)$. The concomitant rise $(P<0.001)$ in milk 10-O-18:0, found only in trace amounts in the control, was also relevant.

On the other hand, pronounced decreases $(P<0.01)$ were detected in 18:0 and cis-9 18:1, as well as in 18:2n6 and 18:3n-3. Concentrations of UFA present in the fish oil, such as cis-9 16:1, cis-11 18:1, 20:5n-3, and 22:6n-3, and their intermediate metabolites (e.g., 20:1 and 22:1 isomers) were higher in the milk of ewes on the FO treatment $(P<0.05)$.

\section{mRNA Abundance of Candidate Genes}

All RIN values were $\geq 7.7$ and slightly greater in samples from ewes fed FO than in the control (on average, 8.2 vs. 7.9 , respectively; $P<0.05$ ). No differences were observed due to the source of RNA, either MT or MSC (8.1 vs. 8.0; $P>0.05$ ). On average, $15.8 \mu \mathrm{g}$ of RNA were isolated from milk samples and $32.0 \mu \mathrm{g}$ from biopsies $(P<0.01)$. The experimental diet had no effect on the quantity of RNA obtained from each type of sample (on average, 26.7 vs. $21.0 \mu \mathrm{g}$ for the control and FO treatments, respectively; $P>0.10$ ). 
RNA ISOLATION FROM MAMMARY TISSUE OR MILK

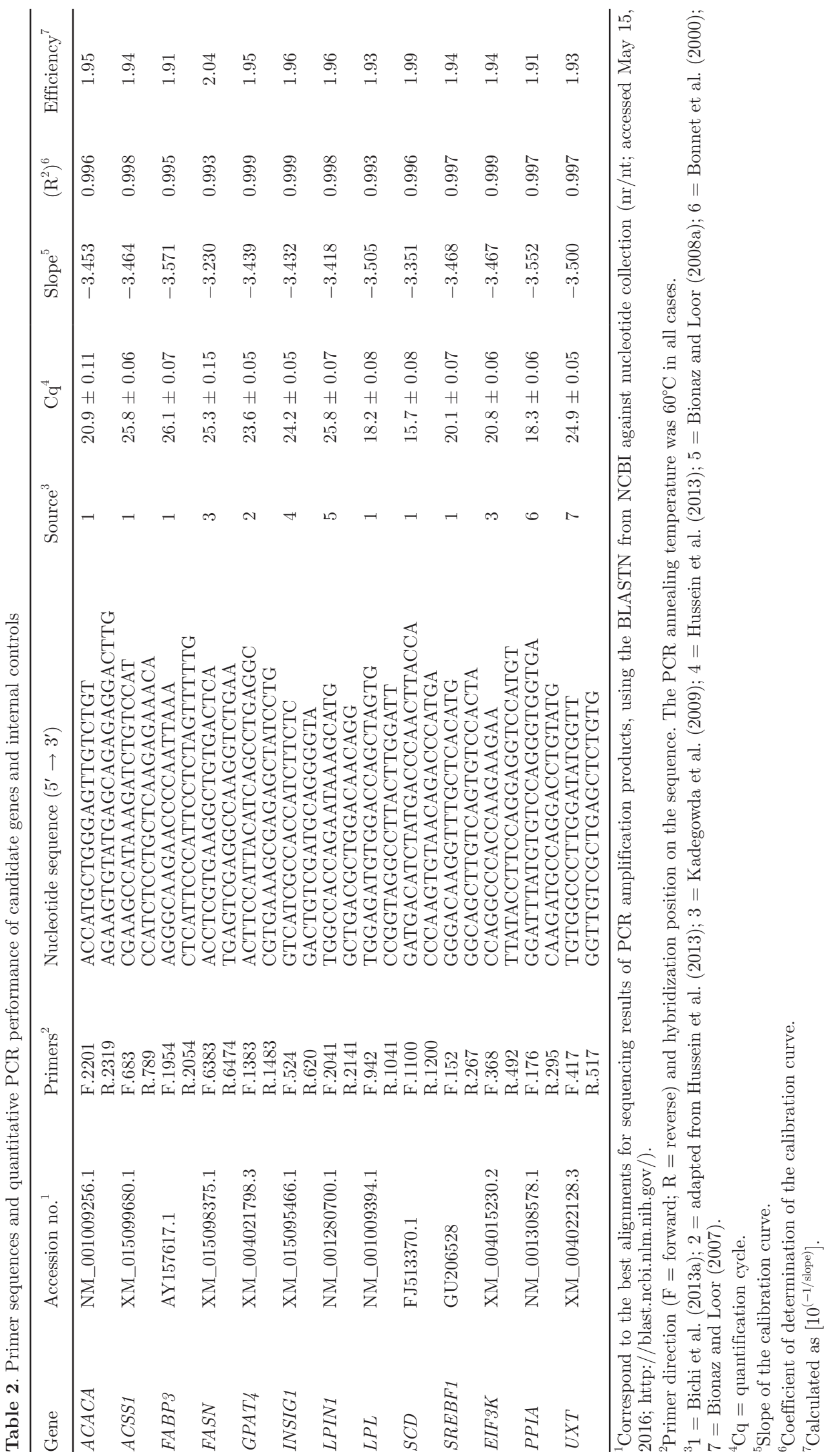


Table 3. Intake, milk yield, milk fat concentration and yield, and SCC in lactating ewes fed the TMR without lipid supplementation (control) or supplemented with $24 \mathrm{~g}$ of fish oil $/ \mathrm{kg}$ of DM $(\mathrm{FO})^{1}$

\begin{tabular}{|c|c|c|c|c|}
\hline \multirow[b]{2}{*}{ Item } & \multicolumn{2}{|c|}{ Treatment } & \multirow[b]{2}{*}{$\mathrm{SED}^{2}$} & \multirow[b]{2}{*}{$P$-value } \\
\hline & Control & FO & & \\
\hline$\overline{\mathrm{DMI}, \mathrm{g} / \mathrm{d}}$ & 2,797 & 2,651 & 264.2 & 0.601 \\
\hline Milk, g/d & 1,465 & 1,921 & 123.9 & 0.014 \\
\hline \multicolumn{5}{|l|}{ Fat } \\
\hline$\%$ & 5.87 & 4.19 & 0.262 & 0.001 \\
\hline $\mathrm{g} / \mathrm{d}$ & 84.4 & 81.6 & 4.77 & 0.578 \\
\hline $\mathrm{SCC}, \log _{10} / \mathrm{mL}$ & 4.84 & 4.61 & 0.127 & 0.126 \\
\hline
\end{tabular}

${ }^{1}$ Mean values (covariate-adjusted least squares means) over d 35 and 37.

${ }^{2} \mathrm{SED}=$ standard error of the difference.

The selected reference genes (i.e., PPIA, EIF3K and $U X T)$ were confirmed as the most stable genes among those quantified using both the geNorm and the BestKeeper procedures. Their mRNA abundance was not affected by dietary treatment $(P>0.10)$, but was lower in MSC than in MT $(P<0.05)$. As shown in Figure 1 , the abundance of other transcripts was also lower in MSC (e.g., ACSS1, ACACA, FASN and SREBF1; $P<$ 0.05 ), but reductions due to the experimental diet were similarly detected in both RNA sources.

Dietary fish oil supplementation decreased $(P<0.05)$ the mRNA abundance of candidate genes coding for enzymes involved in FA activation (ACSS1), de novo synthesis $(A C A C A$ and $F A S N)$, and esterification of $\mathrm{FA}$ to glycerol (LPIN1), as well as the INSIG1 transcription factor $(P<0.05$; Figure 1$)$. The $L P L$ gene (involved in FA uptake from plasma lipoproteins) showed erratic behavior and the interaction diet $\times$ type of sample did not reach the required $P$-level to be considered significant $(P=0.074)$. Addition of FO to the diet did not significantly affect the transcript abundance of $F A B P 3$, GPAT4, and SCD genes and SREBF1 transcription factor $(P>0.05)$.

\section{DISCUSSION}

By crossing traditional boundaries between academic disciplines, nutrigenomics represents a valuable tool to move forward our knowledge of the nutritional regulation of mammary lipogenesis (Bauman et al., 2011; Bionaz et al., 2015). In dairy ruminants, however, much work remains to be done to unravel the complex nutrient-gene interactions. In this regard, isolating RNA from milk would be a useful and cost-effective tool that may avoid distress to animals and facilitate the collection of samples in time series experiments (Boutinaud et al., 2002; Mura et al., 2013; Suárez-Vega et al., 2015).

In line with the MFD syndrome induced in ewes fed the diet supplemented with FO, our results showed a downregulation of several analyzed genes related to mammary lipid synthesis (i.e., ACSS1, ACACA, FASN, LPIN1, and INSIG1) in the 2 evaluated RNA sources, MSC and MT biopsies. The results also showed stable transcript abundances in other candidate genes, such as FABP3, GPAT4, or SCD. These consistent effects of FO in MSC and MT biopsies, together with the relationship between qPCR results in both type of samples ( $r=0.914 ; P<0.001$ ), would support the feasibility of MSC as an alternative RNA source for nutrigenomic analyses in sheep.

Overall, these similarities agree with those reported in dairy goats (Boutinaud et al., 2002), dairy cows (Cánovas et al., 2014), and lactating beef cows (Murrieta et al., 2006). However, Angulo et al. (2012) observed a clear discrepancy in dairy cows between samples of MT and antibody-captured mammary epithelial cells from milk. This latter, noninvasive technique did not allow to detect any of the significant reductions in the transcript abundance of lipogenic genes found in MT during marine lipid-induced MFD. Because potential interspecies and -breed differences appear unlikely in this case, divergent results among trials might be explained, at least to some extent, by methodological features in RNA extraction from milk affecting its quality (Cánovas et al., 2014).

In our study, RNA isolated from MSC showed good RIN values (8.0 on average) that were slightly better in the FO samples (8.1), which contrasts with the decrease in this quality indicator observed by Angulo et al. (2012) in cows consuming marine lipids. Further research would be necessary to elucidate whether this inconsistency is attributable to laboratory techniques or to their interaction with dietary treatments. In goats, we only know one available study on this subject and it reports no effect of palm oil supplementation on the RIN value of RNA obtained from MSC (Tudisco et al., 2015). In sheep, we are not aware of other nutrigenomic studies using noninvasive sampling methods, the infor- 
Table 4. Milk fatty acid (FA) composition in lactating ewes fed the TMR without lipid supplementation (control) or supplemented with $24 \mathrm{~g}$ of fish oil $/ \mathrm{kg}$ of DM $(\mathrm{FO})^{1}$

\begin{tabular}{|c|c|c|c|c|}
\hline \multirow[b]{2}{*}{ FA, g/100 $\mathrm{g}$ of total FA } & \multicolumn{2}{|c|}{ Treatment } & \multirow[b]{2}{*}{$\mathrm{SED}^{2}$} & \multirow[b]{2}{*}{$P$-value } \\
\hline & Control & $\mathrm{FO}$ & & \\
\hline $4: 0$ & 2.44 & 2.38 & 0.180 & 0.741 \\
\hline $6: 0$ & 2.77 & 2.91 & 0.205 & 0.517 \\
\hline $8: 0$ & 3.03 & 3.35 & 0.311 & 0.344 \\
\hline 10:0 & 10.62 & 10.63 & 0.570 & 0.984 \\
\hline cis-9 10:1 & 0.26 & 0.31 & 0.026 & 0.154 \\
\hline $12: 0$ & 6.15 & 5.92 & 0.243 & 0.392 \\
\hline cis-9 12:1 & 0.10 & 0.09 & 0.019 & 0.516 \\
\hline $14: 0$ & 12.27 & 12.51 & 0.276 & 0.433 \\
\hline cis-9 14:1 & 0.22 & 0.20 & 0.040 & 0.651 \\
\hline $15: 0$ & 0.98 & 0.85 & 0.048 & 0.048 \\
\hline $16: 0$ & 25.96 & 25.71 & 1.286 & 0.855 \\
\hline cis-9 16:1 & 0.79 & 1.08 & 0.145 & 0.097 \\
\hline trans $-6+7+816: 1$ & 0.07 & 0.30 & 0.057 & 0.011 \\
\hline trans-9 16:1 & 0.09 & 0.35 & 0.067 & 0.012 \\
\hline $17: 0$ & 0.59 & 0.73 & 0.035 & 0.010 \\
\hline $18: 0$ & 7.89 & 1.53 & 0.444 & $<0.001$ \\
\hline 10-O-18:0 & $<0.01$ & 0.57 & 0.052 & $<0.001$ \\
\hline cis-9 $18: 1^{3}$ & 12.25 & 6.75 & 0.682 & $<0.001$ \\
\hline cis-11 18:1 & 0.59 & 0.99 & 0.026 & $<0.001$ \\
\hline$\Sigma$ cis $18: 1$ & 13.26 & 7.91 & 0.712 & $<0.001$ \\
\hline trans-10 18:1 & 0.94 & 1.86 & 0.474 & 0.109 \\
\hline trans-11 18:1 & 1.28 & 4.84 & 0.951 & 0.013 \\
\hline$\Sigma$ trans $18: 1$ & 2.77 & 8.58 & 0.719 & $<0.001$ \\
\hline cis-9,cis-12 18:2 & 2.59 & 1.54 & 0.097 & $<0.001$ \\
\hline cis-9,trans-12 18:2 & 0.07 & 0.13 & 0.022 & 0.038 \\
\hline trans-9,cis-12 18:2 & 0.03 & 0.06 & 0.009 & 0.011 \\
\hline trans-11,cis-15 18:2 & 0.05 & 0.42 & 0.019 & $<0.001$ \\
\hline trans-11,trans-15 18:2 & 0.02 & 0.07 & 0.004 & $<0.001$ \\
\hline$\Sigma$ nonconjugated 18:2 & 2.93 & 2.43 & 0.100 & 0.004 \\
\hline cis-9,trans-11 CLA $^{4}$ & 0.54 & 2.19 & 0.492 & 0.020 \\
\hline trans-9,cis-11 CLA & 0.03 & 0.10 & 0.018 & 0.012 \\
\hline trans-10,cis-12 CLA & 0.003 & 0.012 & 0.0020 & 0.007 \\
\hline$\Sigma \mathrm{CLA}$ & 0.70 & 2.40 & 0.480 & 0.017 \\
\hline cis-9,cis-12,cis-15 $18: 3^{5}$ & 0.60 & 0.37 & 0.042 & 0.003 \\
\hline cis-11 20:1 & 0.04 & 0.29 & 0.012 & $<0.001$ \\
\hline$\Sigma 20: 1$ & 0.09 & 0.39 & 0.017 & $<0.001$ \\
\hline cis-5,cis-8,cis-11,cis-14,cis-17 20:5 & 0.04 & 0.45 & 0.034 & $<0.001$ \\
\hline$\Sigma$ unsaturated C20 & 0.38 & 1.32 & 0.070 & $<0.001$ \\
\hline$\Sigma 22: 1$ & 0.04 & 0.26 & 0.018 & $<0.001$ \\
\hline cis-4,cis-7,cis-10,cis-13,cis-16 22:5 & 0.04 & 0.14 & 0.026 & 0.011 \\
\hline cis-7,cis-10,cis-13,cis-16,cis-19 22:5 & 0.11 & 0.91 & 0.093 & $<0.001$ \\
\hline cis-4,cis-7,cis-10,cis-13,cis-16,cis-19 22:6 & 0.04 & 0.92 & 0.036 & $<0.001$ \\
\hline$\Sigma$ unsaturated $\mathrm{C} 22$ & 0.27 & 2.30 & 0.139 & $<0.001$ \\
\hline
\end{tabular}

mation on the use of milk as an RNA source being still too scant in small ruminants (Mura et al., 2013; Suárez-Vega et al., 2015).

Besides yielding good quality RNA, the technique used to isolate RNA from MSC (Suárez-Vega et al., 2015) resulted in a greater extraction efficiency (on average, $0.32 \mu \mathrm{g}$ of RNA $/ \mathrm{mL}$ of milk) than that previously reported in dairy sheep (on average, $0.02 \mu \mathrm{g}$ of RNA/mL of milk; Mura et al., 2013), which might be accounted for by the sampling protocol maximizing the presence of somatic cells in milk (Gonzalo et al., 1994). This would be in line with the reported increase in epithelial cell concentration and extracted RNA quantity in goat milk samples collected 30 min after regular milking (Boutinaud et al., 2002).

In any event, transcript abundances were generally lower in MSC than in MT, not only for candidate but also for reference genes, even though the same initial amount of RNA was used in both types of samples. This may be due, at least in part, to isolation of bacterial 

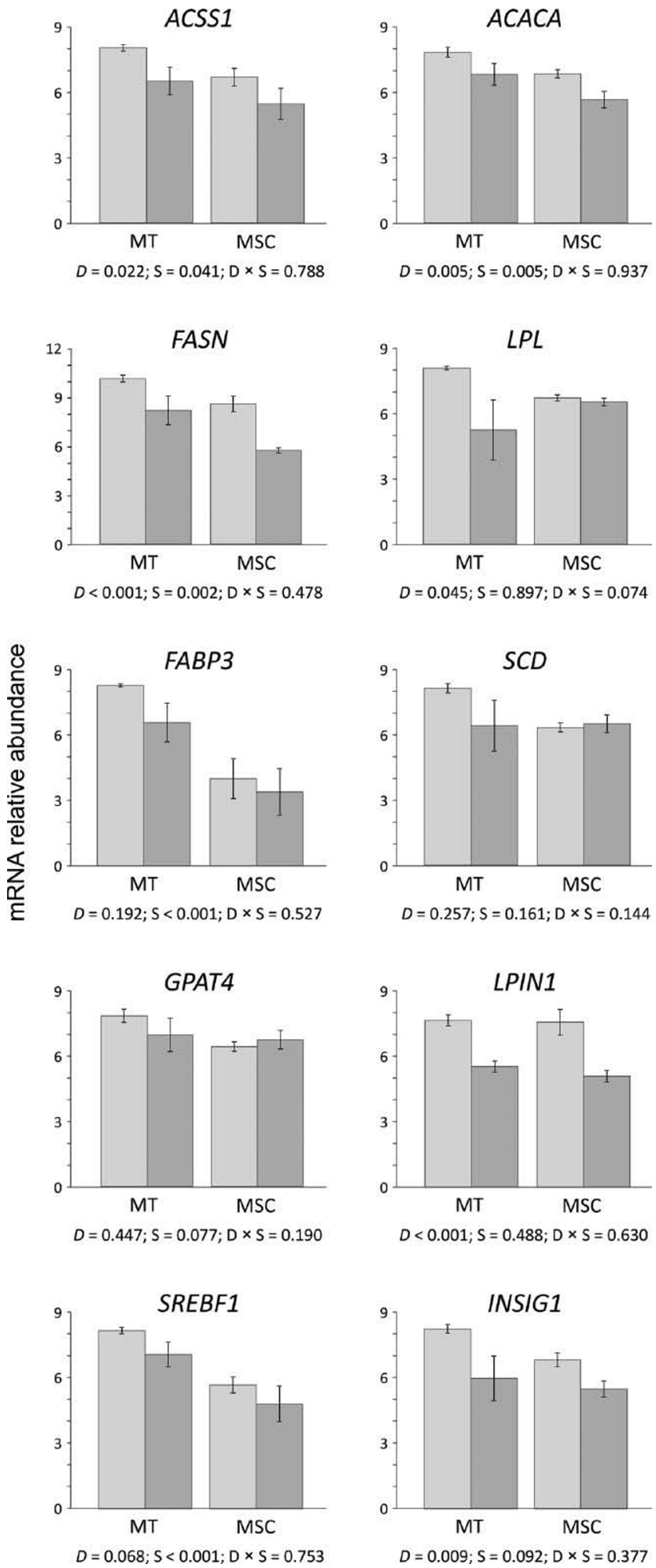

Figure 1. The mRNA relative abundance $\left(\log _{2}\right.$ transformed data) of candidate genes in the mammary tissue (MT) and milk somatic cells (MSC) of lactating ewes fed the TMR without lipid supplementation (control; light gray) or supplemented with $24 \mathrm{~g}$ of fish oil $/ \mathrm{kg}$ of DM (FO; dark gray). Vertical bars represent the SEM. The statistical probabilities ( $P$-value) for the effects of experimental diet (D), RNA source $(\mathrm{S})$, and their interaction $(\mathrm{D} \times \mathrm{S})$ are shown below each panel.
RNA in milk. In experiments with MSC samples from cows, bacterial RNA has been reported to represent as much as 20 to $25 \%$ of total reads in RNA-sequencing analysis (Cánovas et al., 2014; Medrano et al., 2014).

Concerning the MFD syndrome, which was elicited in this experiment as a mean to cause differences to study the feasibility of MSC and MT as RNA sources, several experiments conducted by our team have already examined the association between diet supplementation with marine lipids and MFD in dairy ewes (e.g., Toral et al., 2010, 2015a, 2016; Bichi et al., 2013b); therefore, this part will only be discussed briefly.

Addition of FO is seldom accompanied by other relevant changes in ewe performance (Capper et al., 2007; Bichi et al., 2013b; Toral et al., 2016), but, unexpectedly, it increased milk yield in this trial. This response might be related to the energy spared in FO due to the inhibition of mammary lipogenesis, as previously shown in CLA-induced MFD (Lock et al., 2006; Weerasinghe et al., 2012), but not in marine lipid-induced MFD (Capper et al., 2007; Bichi et al., 2013b; Carreño et al., 2016) in sheep. The large increase in milk production would explain the lack of changes in milk fat output, even though the associated reduction in milk fat percentage behaved as expected (Capper et al., 2007; Toral et al., 2010; Bichi et al., 2013b) and designed.

The origin of diet-induced MFD, and the underlying downregulation of mammary lipogenic genes, appears to lie in altered ruminal biohydrogenation pathways leading to increased outflow of specific FA that inhibit milk fat synthesis (Shingfield et al., 2010; Bauman et al., 2011). In our case, neither the limited increase in the concentration of some CLA isomers in milk (namely trans-10,cis-12 and trans-9,cis-11 18:2) nor the lack of variation in trans-10 18:1 allow to support a major role of these biohydrogenation metabolites (Gervais et al., 2009; Shingfield et al., 2010; Hussein et al., 2013). Some recent studies (e.g., Kairenius et al., 2015; Toral et al., 2015a, 2016) have suggested the contribution of less well-known antilipogenic compounds, such as certain FA supplied with fish oil, intermediates of altered 18:3n-3 biohydrogenation pathways, or oxo-FA. Our findings, in particular the increase in cis-9 16:1, cis-11 18:1, trans-11,cis-15 and trans-11,trans-15 18:2, and 10O-18:0, would support this speculation.

Regarding the downregulation of some candidate genes involved in the lipid metabolism in the mammary gland, our results agree with previous studies in dairy ewes (Hussein et al., 2013; Carreño et al., 2016) and cows (Peterson et al., 2003; Harvatine and Bauman, 2006; Bionaz et al., 2015), establishing a causal relationship between increases in antilipogenic FA in milk and this downregulation. However, some variations in gene expression are hardly correlated with other changes in 
milk FA composition. For example, decreased mRNA abundance of genes coding for enzymes related to de novo FA synthesis, through activation of acetate to acetyl-CoA (ACSS1), its subsequent carboxylation to malonyl-CoA ( $A C A C A)$, and the elongation of the hydrocarbon chain up to 16:0 (FASN), had little effect on the relative proportions of FA with 16 or fewer carbon atoms, mostly derived from this metabolic pathway (Bernard et al., 2008; Bionaz and Loor, 2008b). Previous reports on the effects of $\mathrm{FO}$ in dairy ewes have also shown limited variation in de novo FA concentrations in milk (Toral et al., 2015a, 2016; Carreño et al., 2016), in contrast with the marked reduction caused by the consumption of plant lipids (e.g., Mele et al., 2006; Castro-Carrera et al., 2015). Furthermore, increased availability of preformed long-chain FA supplied with FO does not appear to be accompanied by evident improvements in mammary FA uptake in sheep. The decrease in $L P L$ mRNA abundance in the FO treatment would support the inhibition of this metabolic pathway during MFD in sheep (Hussein et al., 2013; Carreño et al., 2016). The statistical analysis did not show significant differences in the ability of MT or MSC samples to detect this inhibition $(P=0.074)$. However, it is probably worth mentioning that the mRNA abundances of this gene presented a high deviation in MT samples collected from ewes fed the diet supplemented with FO (see Figure 1). This may be related to the fact that $L P L$ is also expressed in mammary cell populations other than epithelial secretory cells, such as macrophages and interstitial cells (Camps et al., 1990; Bernard et al., 2008), and its mRNA abundance has been observed to be decreased by fish oil n-3 PUFA in human and murine macrophages (Michaud and Renier, 2001). In this regard, Boutinaud et al. (2013) suggested that the nonspecific expression of $L P L$ may account for the lack of variation in its mRNA abundance in response to the effect of once daily milking in antibody-captured mammary epithelial cells in cows compared with reductions found in biopsied MT.

No difference due to FO was detected in the transcript abundance of the other studied candidate gene with a role in FA uptake and transport, FABP3. Available information of the nutritional regulation of this gene is very scarce and inconsistent, with reductions (Carreño et al., 2016), no changes (Hussein et al., 2013), or increases (Invernizzi et al., 2010) during MFD, which would disallow from considering that it has a major role in the low-fat milk syndrome.

Neither did we observe variations due to the effect of experimental diets on $S C D$ abundance in any of the 2 RNA sources. This gene, which codes for the enzyme $\Delta^{9}$-desaturase, plays a key role in mammary lipogenesis (Bernard et al., 2013) and has been shown to be downregulated in cows and ewes during MFD (Ahnadi et al., 2002; Angulo et al., 2012; Carreño et al., 2016). Still, other authors report no changes or even increases in $S C D$ transcript abundance in marine lipid-induced MFD (Harvatine and Bauman, 2006; Invernizzi et al., 2010; Bichi et al., 2013a), which may be attributed to the particular relevance of post-transcriptional events in the nutritional regulation of its expression (Bernard et al., 2013). Consistent with the mRNA results, the milk fat concentration of cis-9 10:1, cis-9 12:1, and cis-9 14:1 (which are synthesized almost exclusively in the mammary gland through $\Delta^{9}$-desaturase activity; Bernard et al., 2013; Toral et al., 2015b) were not affected by FO. Changes in other milk cis-9-containing FA are most likely explained by their supply with the FO (as it contains, for instance, approximately $4.5 \%$ of cis-9 16:1) or by differences in the availability of substrates for the SCD enzyme (e.g., 18:0, and trans-11 and trans-12 18:1).

Following the pathways of mammary lipogenesis, FA derived from de novo synthesis, plasma uptake, and $\Delta^{9}$-desaturation are almost entirely esterified to glycerol before secretion in milk fat globules (Bernard et al., 2008). The effect of FO on the 2 candidate genes (LPIN1 and GPAT4) involved in triacylglycerol synthesis that we studied, namely a decrease in the mRNA abundance of the former and no variation in the latter, contrast with the changes recorded by Carreño et al. (2016; no changes in LPIN1 and decreases in GPAT4). Nonetheless, it has been shown that alterations in either of the 2 enzymes would be rate limiting (Takeuchi and Reue, 2009), which would lead to similar consequences regardless of the gene affected. In addition to catalyzing the penultimate step in triacylglycerol synthesis, LPIN1 appears to interact with some transcription factors, such as PPARA, and have a key role in the expression of other lipogenic genes (Takeuchi and Reue, 2009); however, its involvement in dairy ruminants remains to be determined.

Available information concurs with a prominent function of $S R E B F 1$ signaling pathway in the transcriptional regulation of mammary lipogenesis (Harvatine and Bauman, 2006; Bionaz et al., 2015; Xu et al., 2016). This would be in agreement with the lower transcript abundance of INSIG1 with FO in both MSC and MT, as simultaneous decreases in the mRNA levels of this transcription factor and $S R E B F 1$ are common features of MFD (Harvatine and Bauman, 2006; Hussein et al., 2013; Carreño et al., 2016). Nevertheless, reductions in the latter due to FO were above the threshold for statistical significance in the present study $(P=0.068)$. According to the potential role of INSIG1 as inhibitor of SREBP1 protein activation (Bernard et al., 2008; Bauman et al., 2011), a negative feedback regulation 
mechanism cannot be ruled out (Xu et al., 2016). However, decreased INSIG1 expression did not appear to counteract the decrease in SREBP1 activity, as suggested by the reductions in the mRNA abundance of its target genes, such as ACACA or FASN (Bernard et al., 2008; Xu et al., 2016).

\section{CONCLUSIONS}

In ewes fed the diet supplemented with FO, downregulation of several genes related to mammary lipid synthesis (i.e., ACSS1, ACACA, FASN, LPIN1, and INSIG1) is consistent with the elicited MFD syndrome, whereas stable transcript abundances are showed in other candidate genes (i.e., FABP3, GPAT4, and $S C D$ ). The steady effects of FO in both types of samples, milk somatic cells and mammary tissue biopsies, support the feasibility of milk as an alternative RNA source for nutrigenomic analyses in sheep.

\section{ACKNOWLEDGMENTS}

This work was supported by the Ministry of Economy and Competitiveness (MINECO, Spain; AGL201454587, co-funded by the European Regional Development Fund, European Union). P. G. Toral gratefully acknowledges receipt of a postdoctoral research contract from the MINECO (Juan de la Cierva program).

\section{REFERENCES}

Ahnadi, C. E., N. Beswick, L. Delbecchi, J. J. Kennelly, and P. Lacasse. 2002. Addition of fish oil to diets for dairy cows. II. Effects on milk fat and gene expression of mammary lipogenic enzymes. J. Dairy Res. 69:521-531.

Angulo, J., L. Mahecha, K. Nuernberg, G. Nuernberg, D. Dannenberger, M. Olivera, M. Boutinaud, C. Leroux, E. Albrecht, and L. Bernard. 2012. Effects of polyunsaturated fatty acids from plant oils and algae on milk fat yield and composition are associated with mammary lipogenic and SREBF1 gene expression. Animal 6:1961-1972

Ankom. 2006a. Acid detergent fiber in feeds. Filter bag technique (For A2000, A2000I). Ankom Technology Method 8. Ankom Technology Corp., Macedon, NY.

Ankom. 2006b. Neutral detergent fiber in feeds. Filter bag technique (For A2000, A2000I). Ankom Technology Method 9. Ankom Technology Corp., Macedon, NY.

Bauman, D. E., K. J. Harvatine, and A. L. Lock. 2011. Nutrigenomics, rumen-derived bioactive fatty acids, and the regulation of milk fat synthesis. Annu. Rev. Nutr. 31:299-319.

Bernard, L., C. Leroux, and Y. Chilliard. 2008. Expression and nutritional regulation of lipogenic genes in the ruminant lactating mammary gland. Adv. Exp. Med. Biol. 606:67-108.

Bernard, L., C. Leroux, and Y. Chilliard. 2013. Expression and nutritional regulation of stearoyl-CoA desaturase genes in the ruminant mammary gland: Relationship with milk fatty acid composition. Pages 161-193 in Stearoyl-CoA Desaturase Genes in Lipid Metabolism. J. M. Ntambi, ed. Springer Science+Business Media, New York, NY.

Bichi, E., P. Frutos, P. G. Toral, D. Keisler, G. Hervás, and J. J. Loor. 2013a. Dietary marine algae and its influence on tissue gene net- work expression during milk fat depression in dairy ewes. Anim. Feed Sci. Technol. 186:36-44

Bichi, E., G. Hervás, P. G. Toral, J. J. Loor, and P. Frutos. 2013b. Milk fat depression induced by dietary marine algae in dairy ewes: Persistency of milk fatty acid composition and animal performance responses. J. Dairy Sci. 96:524-532.

Bionaz, M., and J. J. Loor. 2007. Identification of reference genes for quantitative real-time PCR in the bovine mammary gland during the lactation cycle. Physiol. Genomics 29:312-319.

Bionaz, M., and J. J. Loor. 2008a. ACSL1, AGPAT6, FABP3, LPIN1, and $S L C 27 A 6$ are the most abundant isoforms in bovine mammary tissue and their expression is affected by stage of lactation. J. Nutr. 138:1019-1024.

Bionaz, M., and J. J. Loor. 2008b. Gene networks driving bovine milk fat synthesis during the lactation cycle. BMC Genomics 9:366.

Bionaz, M., J. Osorio, and J. J. Loor. 2015. Nutrigenomics in dairy cows: Nutrients, transcription factors, and techniques. J. Anim. Sci. 93:5531-5553.

BOE. 2013. Royal Decree 53/2013, of 8 February, on the protection of animals used for experimental purposes. Pages 11370-11421 in Boletín Oficial del Estado. Spanish Government Publishing, Madrid, Spain.

Bonnet, M., L. Bernard, S. Bes, and C. Leroux. 2013. Selection of reference genes for quantitative real-time PCR normalisation in adipose tissue, muscle, liver and mammary gland from ruminants. Animal 7:1344-1353

Bonnet, M., C. Leroux, Y. Faulconnier, J. F. Hocquette, F. Bocquier, P. Martin, and Y. Chilliard. 2000. Lipoprotein lipase activity and mRNA are up-regulated by refeeding in adipose tissue and cardiac muscle of sheep. J. Nutr. 130:749-756.

Boutinaud, M., L. Galio, V. Lollivier, L. Finot, S. Wiart, D. Esquerre, and E. Devinoy. 2013. Unilateral once daily milking locally induces differential gene expression in both mammary tissue and milk epithelial cells revealing mammary remodeling. Physiol. Genomics 45:973-985.

Boutinaud, M., H. Rulquin, D. H. Keisler, J. Djiane, and H. Jammes. 2002. Use of somatic cells from goat milk for dynamic studies of gene expression in the mammary gland. J. Anim. Sci. 80:12581269

Camps, L., M. Reina, M. Llobera, S. Vilaró, and T. Olivecrona. 1990. Lipoprotein lipase: Cellular origin and functional distribution. Am. J. Physiol. 258:C673-C681.

Cánovas, A., G. Rincón, C. Bevilacqua, A. Islas-Trejo, P. Brenaut, R. C. Hovey, M. Boutinaud, C. Morgenthaler, M. K. VanKlompenberg, P. Martin, and J. F. Medrano. 2014. Comparison of five different RNA sources to examine the lactating bovine mammary gland transcriptome using RNA-Sequencing. Sci. Rep. 4:5297.

Capper, J. L., R. G. Wilkinson, A. M. Mackenzie, and L. A. Sinclair. 2007. The effect of fish oil supplementation of pregnant and lactating ewes on milk production and lamb performance. Animal 1:889-898

Carreño, D., G. Hervás, P. G. Toral, T. Castro-Carrera, and P. Frutos 2016. Fish oil-induced milk fat depression and associated downregulation of mammary lipogenic genes in dairy ewes. J. Dairy Sci. 99

Castro-Carrera, T., P. Frutos, C. Leroux, Y. Chilliard, G. Hervás, A. Belenguer, L. Bernard, and P. G. Toral. 2015. Dietary sunflower oil modulates milk fatty acid composition without major changes in adipose and mammary tissue fatty acid profile or related gene mRNA abundance in sheep. Animal 9:582-591.

Gervais, R., J. W. McFadden, A. J. Lengi, B. A. Corl, and P. Y. Chouinard. 2009. Effects of intravenous infusion of trans-10,cis-12 18:2 on mammary lipid metabolism in lactating dairy cows. J. Dairy Sci. 92:5167-5177.

Gonzalo, C., J. A. Carriedo, J. D. Gomez, L. D. Gomez, and F. San Primitivo. 1994. Diurnal variation in the somatic cell count of ewe milk. J. Dairy Sci. 77:1856-1859.

Harvatine, K. J., and D. E. Bauman. 2006. SREBP1 and thyroid hormone responsive spot 14 (S14) are involved in the regulation of bovine mammary lipid synthesis during diet-induced milk fat depression and treatment with CLA. J. Nutr. 136:2468-2474. 
Hussein, M., K. H. Harvatine, W. M. P. B. Weerasinghe, L. A. Sinclair, and D. E. Bauman. 2013. Conjugated linoleic acid-induced milk fat depression in lactating ewes is accompanied by reduced expression of mammary genes involved in lipid synthesis. J. Dairy Sci. 96:3825-3834.

Invernizzi, G., B. J. Thering, M. A. McGuire, G. Savoini, and J. J. Loor. 2010. Sustained upregulation of stearoyl-CoA desaturase in bovine mammary tissue with contrasting changes in milk fat synthesis and lipogenic gene networks caused by lipid supplements. Funct. Integr. Genomics 10:561-575.

ISO. 1999a. Animal feeding stuffs - Determination of moisture and other volatile matter content. ISO 6496:1999. International Organization for Standardization (ISO), Geneva, Switzerland.

ISO. 1999b. Whole milk-Determination of milkfat, protein and lactose content - Guidance on the operation of mid-infrared instruments. ISO 9622:1999. ISO, Geneva, Switzerland.

ISO. 2002. Animal feeding stuffs-Determination of crude ash. ISO 5984:2002. ISO, Geneva, Switzerland.

ISO. 2006. Milk - Enumeration of somatic cells-Part 2: Guidance on the operation of fluoro-opto-electronic counters. ISO 13366-2:2006 ISO, Geneva, Switzerland.

ISO. 2009. Animal feeding stuffs-Determination of nitrogen content and calculation of crude protein content-Part 2: Block digestion and steam distillation method. ISO 5983-2:2009. ISO, Geneva, Switzerland.

Kadegowda, A. K. G., M. Bionaz, B. Thering, L. S. Piperova, R. A. Erdman, and J. J. Loor. 2009. Identification of internal control genes for quantitative polymerase chain reaction in mammary tissue of lactating cows receiving lipid supplements. J. Dairy Sci. 92:2007-2019.

Kairenius, P., A. Ärölä, H. Leskinen, V. Toivonen, S. Ahvenjärvi, A. Vanhatalo, P. Huhtanen, T. Hurme, J. M. Griinari, and K. J. Shingfield. 2015. Dietary fish oil supplements depress milk fat yield and alter milk fatty acid composition in lactating cows fed grass silage based diets. J. Dairy Sci. 98:5653-5671.

Lock, A. L., B. M. Teles, J. W. Perfield, D. E. Bauman, and L. A. Sinclair. 2006. A conjugated linoleic acid supplement containing trans-10, cis-12 reduces milk fat synthesis in lactating sheep. J. Dairy Sci. 89:1525-1532.

Medrano, J. F., A. Cánovas, and A. Islas-Trejo. 2014. RNA sequencing for the analysis of complex traits in milk: Detection of bacteria. Abstract 137 in Proc. 10th World Congress on Genetics Applied to Livestock Production. Vancouver, Canada. Am. Soc. Anim. Sci., Champaign, IL.

Mele, M., A. Buccioni, F. Petacchi, A. Serra, S. Banni, M. Antongiovanni, and P. Secchiari. 2006. Effect of forage/concentrate ratio and soybean oil supplementation on milk yield, and composition from Sarda ewes. Anim. Res. 55:273-285.

Michaud, S. E., and G. Renier. 2001. Direct regulatory effect of fatty acids on macrophage lipoprotein lipase. Potential role of PPARs. Diabetes 50:660-666.

Mura, M. C., C. Daga, S. Bodano, M. Paludo, S. Luridiana, M. Pazzola, M. L. Dettori, G. M. Vacca, and V. Carcangiu. 2013. Development of a RNA extraction method from milk for gene expression study in the mammary gland of sheep. Mol. Biol. Rep. 40:2169-2173.

Murrieta, C. M., B. W. Hess, E. J. Scholljegerdes, T. E. Engle, K. L. Hossner, G. E. Moss, and D. C. Rule. 2006. Evaluation of milk somatic cells as a source of mRNA for study of lipogenesis in the mammary gland of lactating beef cows supplemented with dietary high-linoleate safflower seeds. J. Anim. Sci. 84:2399-2405.

Peterson, D. G., E. A. Matitashvili, and D. E. Bauman. 2003. Diet-induced milk fat depression in dairy cows results in increased trans- 10,cis-12 CLA in milk fat and coordinate suppression of mRNA abundance for mammary enzymes involved in milk fat synthesis. J. Nutr. 133:3098-3102.

Pfaffl, M. W., A. Tichopad, C. Prgomet, and T. P. Neuvians. 2004. Determination of stable housekeeping genes, differentially regulated target genes and sample integrity: BestKeeper-Excel-based tool using pair-wise correlations. Biotechnol. Lett. 26:509-515.

Shingfield, K. J., S. Ahvenjärvi, V. Toivonen, A. Äröla, K. V. V. Nurmela, P. Huhtanen, and J. M. Griinari. 2003. Effect of dietary fish oil on biohydrogenation of fatty acids and milk fatty acid content in cows. Anim. Sci. 77:165-179.

Shingfield, K. J., L. Bernard, C. Leroux, and Y. Chilliard. 2010. Role of trans fatty acids in the nutritional regulation of mammary lipogenesis in ruminants. Animal 4:1140-1166.

Suárez-Vega, A., B. Gutiérrez-Gil, C. Klopp, C. Robert-Granie, G. Tosser-Klopp, and J. J. Arranz. 2015. Characterization and comparative analysis of the milk transcriptome in two dairy sheep breeds using RNA sequencing. Sci. Rep. 5:18399.

Sukhija, P. S., and D. L. Palmquist. 1988. Rapid method for determination of total fatty-acid content and composition of feedstuffs and feces. J. Agric. Food Chem. 36:1202-1206.

Takeuchi, K., and K. Reue. 2009. Biochemistry, physiology, and genetics of GPAT, AGPAT, and lipin enzymes in triglyceride synthesis. Am. J. Physiol. Endocrinol. Metab. 296:E1195-E1209.

Toral, P. G., G. Hervás, D. Carreño, A. Belenguer, and P. Frutos, 2015a. Comparison of milk fatty acid responses during fish oiland trans-10,cis-12 18:2-induced milk fat depression in dairy ewes. Anim. Feed Sci. Technol. 210:66-73.

Toral, P. G., G. Hervás, D. Carreño, and P. Frutos. 2016. Does supplemental 18:0 alleviate fish oil-induced milk fat depression in dairy ewes? J. Dairy Sci. 99:1133-1144.

Toral, P. G., G. Hervás, and P. Frutos. 2015b. Reductions in milk $\Delta^{9}$-desaturation ratios to oral dosing of cobalt-acetate are accompanied by the downregulation of SCD1 in lactating ewes. J. Dairy Sci. 98:1961-1971.

Toral, P. G., G. Hervás, P. Gómez-Cortés, P. Frutos, M. Juárez, and M. A. de la Fuente. 2010. Milk fatty acid profile and dairy sheep performance in response to diet supplementation with sunflower oil plus incremental levels of marine algae. J. Dairy Sci. 93:1655-1667.

Tudisco, R., B. Chiofalo, L. Addi, V. Lo Presti, R. Rao, S. Calabro', N. Musco, M. Grossi, M. I. Cutrignelli, V. Mastellone, P. Lombardi, and F. Infascelli. 2015. Effect of hydrogenated palm oil dietary supplementation on milk yield and composition, fatty acids profile and stearoyl-CoA desaturase expression in goat milk. Small Rumin. Res. 132:72-78.

Vandesompele, J., K. De Preter, F. Pattyn, B. Poppe, N. Van Roy, A. De Paepe, and F. Speleman. 2002. Accurate normalization of real-time quantitative RT-PCR data by geometric averaging of multiple internal control genes. Genome Biol. 3:RESEARCH0034.

Weerasinghe, W. M. P. B., R. G. Wilkinson, A. L. Lock, M. J. de Veth, D. E. Bauman, and L. A. Sinclair. 2012. Effect of a supplement containing trans-10,cis-12 conjugated linoleic acid on the performance of dairy ewes fed 2 levels of metabolizable protein and at a restricted energy intake. J. Dairy Sci. 95:109-116.

Wickramasinghe, S., G. Rincon, A. Islas-Trejo, and J. Medrano. 2012. Transcriptional profiling of bovine milk using RNA sequencing. BMC Genomics 13:45.

Xu, H. F., J. Luo, W. S. Zhao, Y. C. Yang, H. B. Tian, H. B. Shi, and M. Bionaz. 2016. Overexpression of SREBP1 (sterol regulatory element binding protein 1) promotes de novo fatty acid synthesis and triacylglycerol accumulation in goat mammary epithelial cells. J. Dairy Sci. 99:783-795. 